\title{
Adrenocortical carcinoma with tumour thrombus extension to right atrium: a rare finding in uncommon tumour
}

\author{
Sachin Patil, Vishwajeet Singh, Amit Kumar, Satya Narayan Sankhwar
}

Department of Urology, King George Medical University, Lucknow, Uttar Pradesh, India

\section{Correspondence to} Dr Sachin Patil, drsachin.uro@gmail.com
To cite: Patil $S$, Singh $V$, Kumar A, et al. BMJ Case Rep Published online: [please include Day Month Year] doi:10.1136/bcr-2013200804

\section{DESCRIPTION}

A 30-year-old woman presented with a dull aching pain in the right hypochondrium for 2 years with a history of loss of weight and loss of appetite for 4 months. Clinical examination did not reveal any significant findings. An abdominal ultrasonography revealed a large mass $(10.8 \mathrm{~cm})$ arising from the adrenal gland. Further evaluation with a contrastenhanced CT scan showed a well-defined heterogeneously enhancing soft tissue attenuation lesion measuring $12.7 \times 13.3 \times 13.4 \mathrm{~cm}$ in the right adrenal gland (figures 1-3) with tumoural thrombosis in the inferior vena cava (IVC; figure 4) extending to the right atrium (figure 5). A whole-body scintigraphy was negative for bone metastases. Plasma levels of cortisol, aldosterone, 17-OH-progesterone, dehydroepiandrosterone sulfate and $\delta 4$-androstenedione were normal. A fine-needle aspiration cytology of mass showed findings consistent with adrenocortical carcinoma (ACC; figures 5 and 6). She was advised complete excision of ACC with tumour thrombectomy using cardiopulmonary bypass, but the patient refused surgery. She was given mitotane with three cycles of palliative chemotherapy using cyclophosphamide, doxorubicin and cisplatin. The follow-up after completion of chemotherapy showed partial response with non-progressive tumour thrombus.

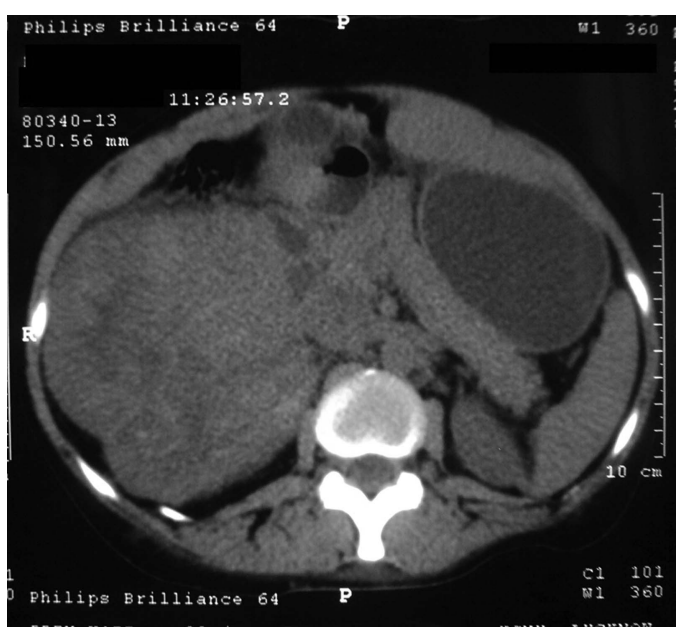

Figure 1 Non-contrast CT scan showing well-defined soft tissue lesion arising from right adrenal gland.

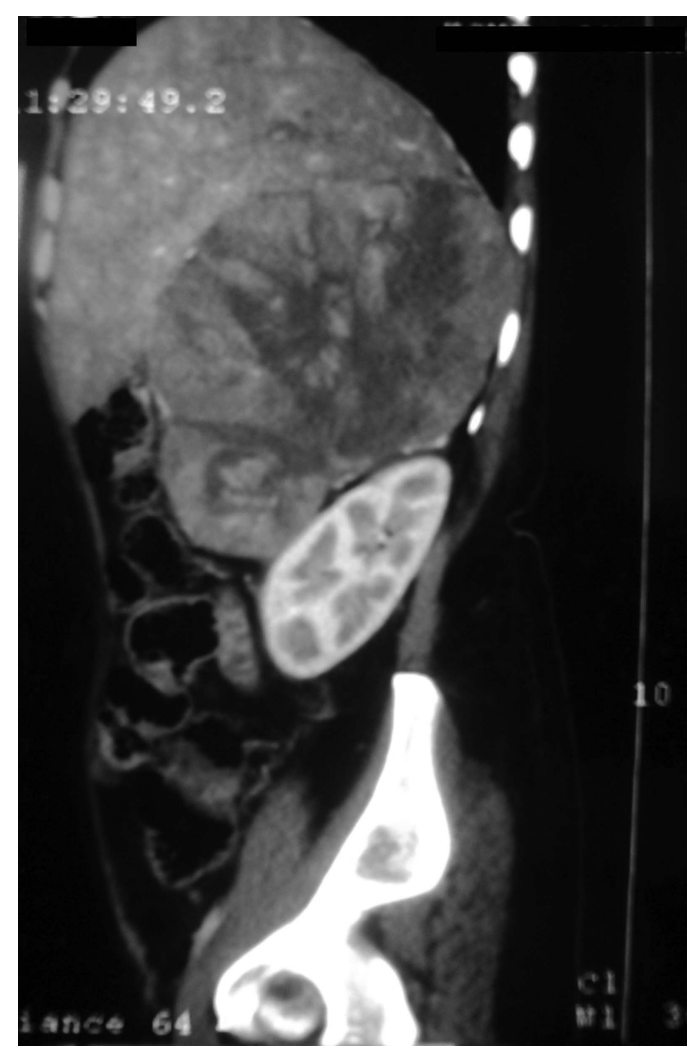

Figure 2 Contrast-enhanced CT scan showing well-defined heterogeneously enhancing soft tissue attenuation lesion arising from right adrenal gland (sagittal view).

ACC is a rare malignancy with incidence of $0.5-$ 2 cases/million/year. ${ }^{1}$ In ACC, the presence of IVC and atrial invasion is considered as tumour extension and not as a metastatic disease. In such cases, a more aggressive surgical approach may give better results. ${ }^{2}$ For patients who are unfit for surgery or who refuse radical surgery, chemotherapy can be tried. To date, mitotane has been the only drug that has proven effective in treating patients with metastatic ACC. ${ }^{2}$ The combination of cisplatin, doxorubicin, etoposide and mitotane has produced clinical response rates of about $50 \%$ even in advanced cases. ${ }^{3}$ 


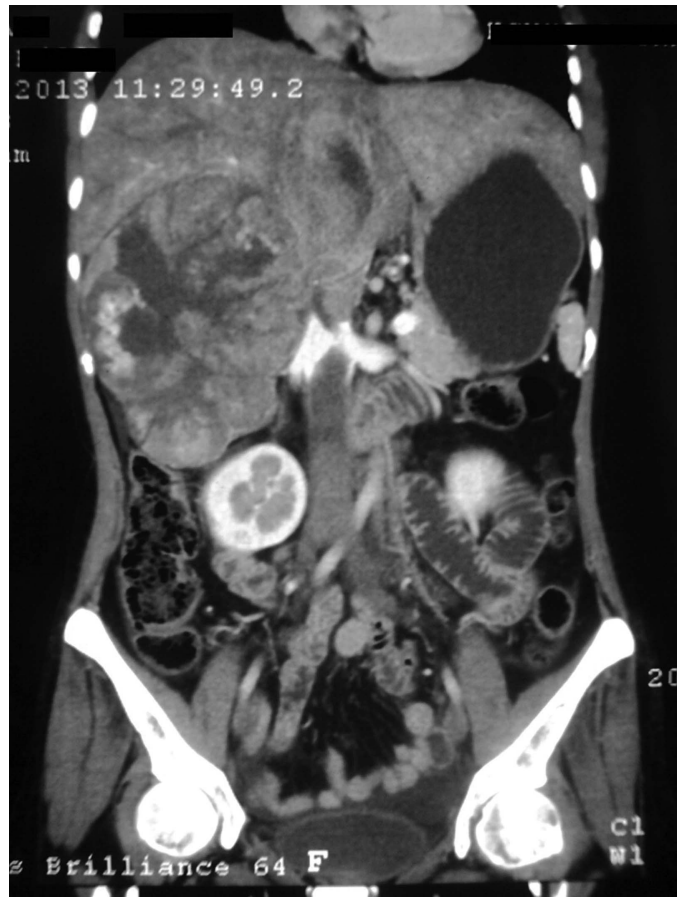

Figure 3 Contrast-enhanced CT scan showing well-defined heterogeneously enhancing soft tissue attenuation lesion arising from right adrenal gland (coronal view).

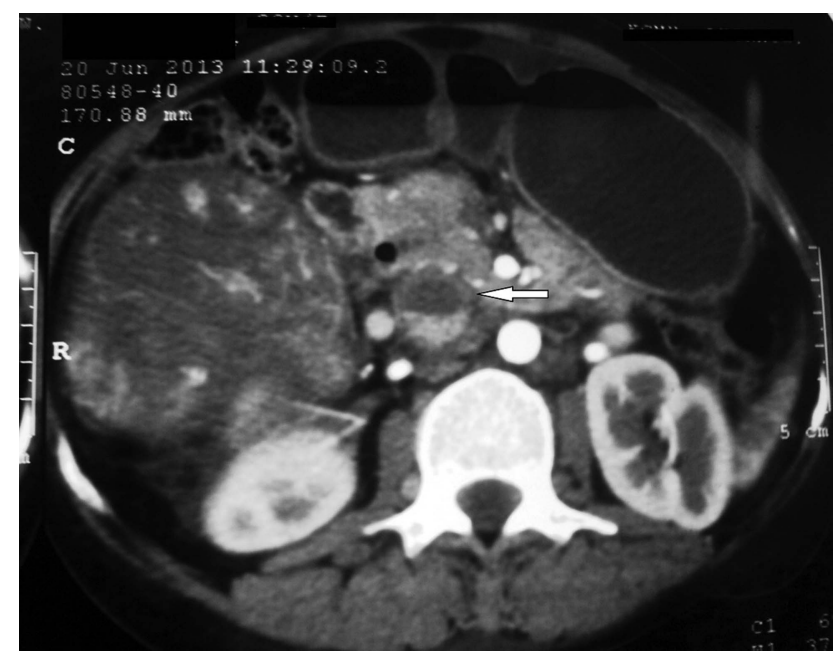

Figure 4 Contrast-enhanced CT scan with axial view showing heterogeneously enhancing soft tissue lesion with inferior vena cava thrombus (indicated by white arrow).

\section{Learning points}

- Adrenocortical cancer is a very rare tumour with a poor prognosis.

- Inferior vena cava (IVC) thrombus in adrenocortical carcinoma is rare and tumour extension up to the right atrium is an extremely rare finding.

- Surgical extirpation is the only curative treatment for large adrenal masses with thrombus extending into the IVC/atrium.

- In patients with advanced adrenocortical carcinoma, mitotane is a useful drug. The patients who do not afford mitotane or who do not tolerate mitotane, other chemotherapeutic agents such as cyclophosphamide, doxorubicin and cisplatin can be tried.

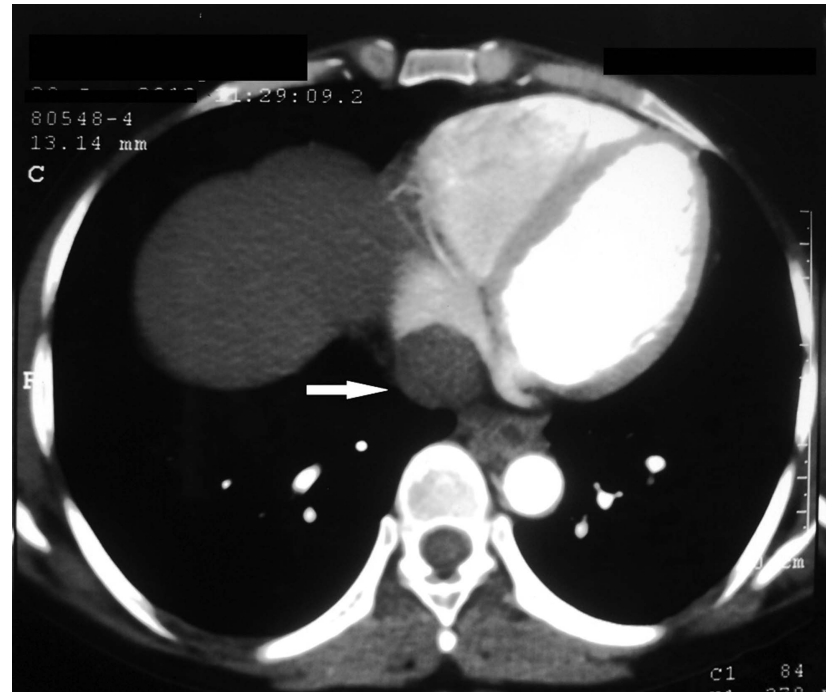

Figure 5 Contrast-enhanced CT scan with axial view showing thrombus in right atrium (indicated by white arrow).

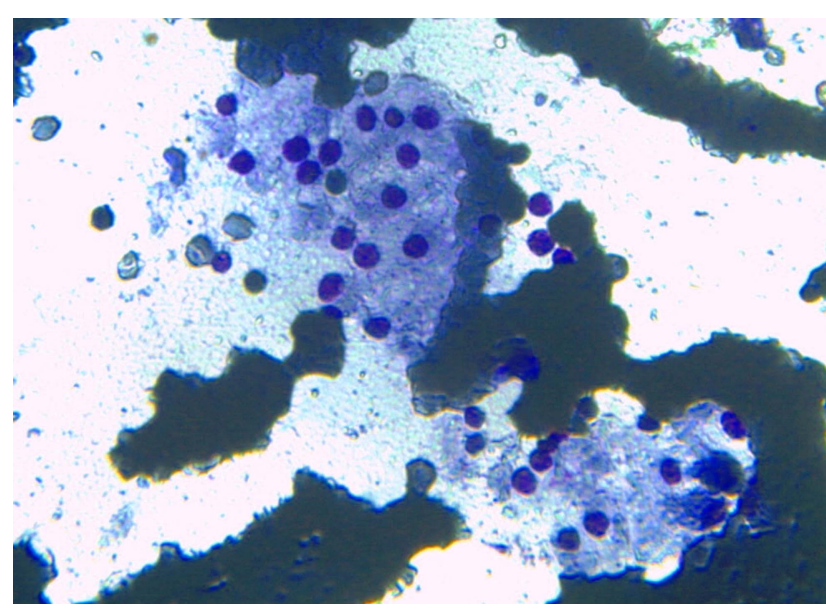

Figure 6 A fine-needle aspiration cytology of the mass showing clusters of pleomorphic cells with an acinar pattern with round to oval nucleus with inconspicuous to prominent nucleoli with abundant, finely vacuolated cytoplasm suggestive of adrenocortical carcinoma.

Competing interests None.

Patient consent Obtained.

Provenance and peer review Not commissioned; externally peer reviewed.

\section{REFERENCES}

1 Meniconi RL, Caronna R, Schiratti M, et al. Adrenocortical carcinoma extending into the inferior vena cava in a patient with right kidney agenesis: surgical approach and review of literature. Int J Surg Case Rep 2012;3:302-4.

2 Wajchenberg BL, Albergaria Pereira MA, Medonca BB, et al. Adrenocortical carcinoma. Cancer 88:711-36.

3 Kirschner LS. Paradigms for adrenal cancer: think globally, act locally. J Clin Endocrincol Metab 2006:91:4250-2. 
Copyright 2013 BMJ Publishing Group. All rights reserved. For permission to reuse any of this content visit http://group.bmj.com/group/rights-licensing/permissions.

BMJ Case Report Fellows may re-use this article for personal use and teaching without any further permission.

Become a Fellow of BMJ Case Reports today and you can:

- Submit as many cases as you like

- Enjoy fast sympathetic peer review and rapid publication of accepted articles

- Access all the published articles

- Re-use any of the published material for personal use and teaching without further permission

For information on Institutional Fellowships contact consortiasales@bmjgroup.com

Visit casereports.bmj.com for more articles like this and to become a Fellow 